\title{
Larvae define spawning habitat of bocaccio rockfish Sebastes paucispinis within and around a large southern California marine reserve
}

\author{
Sean M. Hitchman ${ }^{1,3}$, Nathalie B. Reyns ${ }^{1, *}$, Andrew R. Thompson ${ }^{2}$ \\ ${ }^{1}$ Department of Marine Science and Environmental Studies, University of San Diego, San Diego, California 92110, USA \\ ${ }^{2}$ NOAA Southwest Fisheries Science Center, 8604 La Jolla Shores Drive, La Jolla, California 92037, USA \\ ${ }^{3}$ Present address: Kansas Cooperative Fish \& Wildlife Research Unit, Kansas State University, Manhattan, Kansas 66502, USA
}

\begin{abstract}
Identifying sources of larval production and subsequent dispersal paths is critical for evaluating the efficacy of marine protected areas. We assessed whether the Cowcod Conservation Area (CCA), the largest oceanic reserve in the Southern California Bight (SCB), established to conserve cowcod Sebastes levis, protects essential spawning habitat of another overfished rockfish, bocaccio $S$. paucispinis. To this end we investigated relationships between age-specific (recently hatched, preflexion and postflexion) larval distribution and abundance, environmental indicators (temperature, chlorophyll a), and depth between 2002 and 2004. Larval presence was consistently higher in the CCA than in surrounding areas of the SCB. Abundances of bocaccio larvae from all size classes peaked in 2004, which had relatively low sea surface temperature and high chlorophyll $a$. Depth and sea surface temperature or chlorophyll a were significantly related to the presence of recently hatched larvae, which were most common in cooler western CCA waters where chlorophyll a tended to be highest. In contrast, later stage larvae were not significantly related to depth, indicating that they had been advected from natal locations. Examination of current patterns and the distribution of older larvae suggested that the direction of larval transport varied among years, with mostly northwestward transport in 2002, a cyclonic recirculation feature that may have retained larvae within the CCA in 2003, and southwestward transport in 2004. These results demonstrate that spatial and temporal oceanographic heterogeneity affect larval distribution and transport in this region. We conclude that the CCA protects essential bocaccio spawning habitat and is an important source of bocaccio production in the SCB.
\end{abstract}

KEY WORDS: Depth - Essential fish habitat - Larval fish - Marine protected area $\cdot$ Larval production Resale or republication not permitted without written consent of the publisher

\section{INTRODUCTION}

Anthropogenic impacts in coastal oceans have strained both the structure and function of marine ecosystems (e.g. Jackson et al. 2001, Worm et al. 2006, Halpern et al. 2008). A strategy designed to conserve or enhance marine resources is the implementation of marine protected areas (MPAs). MPAs can benefit fisheries and ecosystems by increasing the density, biomass and diversity of targeted spe- cies relative to non-protected areas (Halpern 2003, Lester et al. 2009, Halpern et al. 2010). MPAs may also promote the recovery of populations depleted by commercial harvesting by providing stocks a refuge from fishing pressure and thereby increasing their reproductive potential (Gell \& Roberts 2003). Given the multiple potential benefits of MPAs, there is currently considerable momentum to establish these reserves in oceans across the globe (Cressey 2011). 
To have a positive impact on sustainable fisheries, it is critical that MPAs serve as a source of larval production (Pelc et al. 2009). Ideally, high production within a reserve will both replenish the population within the reserve through local larval retention and provide a continuously renewable resource that is available to the fishery by seeding adjoining areas through larval dispersal. Despite the dependence of MPA efficacy on larval production, direct measurements of larval output within reserves are scarce (but see Watson et al. 2002, Thompson et al. 2012), and reserve boundaries are typically established without quantification of spatial or temporal patterns of larval production. In this study, we explored how larval production of the overfished rockfish, bocaccio Sebastes paucispinis, varied through time and space within and around the largest marine reserve in California, USA, the Cowcod Conservation Area (CCA).

Although many MPAs have been recently established along the coast of California (California Department of Fish and Game 2008, Hamilton et al. 2010), the CCA is by far the largest. It is located within the Southern California Bight (SCB), and consists of 2 disconnected areas: the principal $\left(\sim 10878 \mathrm{~km}^{2}\right)$ western area lies $75 \mathrm{~km}$ from the smaller $\left(260 \mathrm{~km}^{2}\right)$ eastern section of the reserve (Fig. 1; Thompson et al. 2012). The CCA was established in 2001 to protect the severely overfished cowcod rockfish Sebastes levis and its boundaries were based on locations with historic high catch per unit effort values of cowcod (Butler et al. 2003). Within the bounds of the CCA it is illegal to fish deeper than
$37 \mathrm{~m}$ (Thompson et al. 2012) because adult cowcod most commonly occur at depths between 40 and $297 \mathrm{~m}$ (Love et al. 2002). In addition to cowcod, other rockfish species with similar life histories (e.g. benthic habitat association, relatively sedentary adult stages), such as bocaccio, potentially benefit from the CCA (Yoklavich et al. 2007, Ralston \& MacFarlane 2010). At present, however, it is unknown if the CCA is a source of production for bocaccio and thus whether its presence has the potential to help rebuild this fishery.

Bocaccio was historically a major component of both commercial and recreational fisheries on the west coast of the United States and accounted for 25 to $30 \%$ of the total rockfish catch during the past century (MacCall 2003, Field et al. 2010). Due to unfavorable oceanographic conditions and overfishing, however, stocks diminished by $96 \%$ between 1980 and 2005 (Tolimieri \& Levin 2005) and there were severe declines in catch and abundance in the 1990s (MacCall 2003, Tolimieri \& Levin 2005). As such, the United States National Marine Fisheries Service formally designated bocaccio stocks as overfished in 1999 (MacCall 2003). A ramification of being declared overfished is a requirement for fisheries managers to identify and protect essential fish habitat which includes, in part, 'waters and substrate necessary to fish for spawning, breeding, feeding, or growth to maturity' (National Oceanic and Atmospheric Administration 2006). The overarching goal of this study was to discern whether the CCA protects bocaccio spawning habitat; to this end we measured

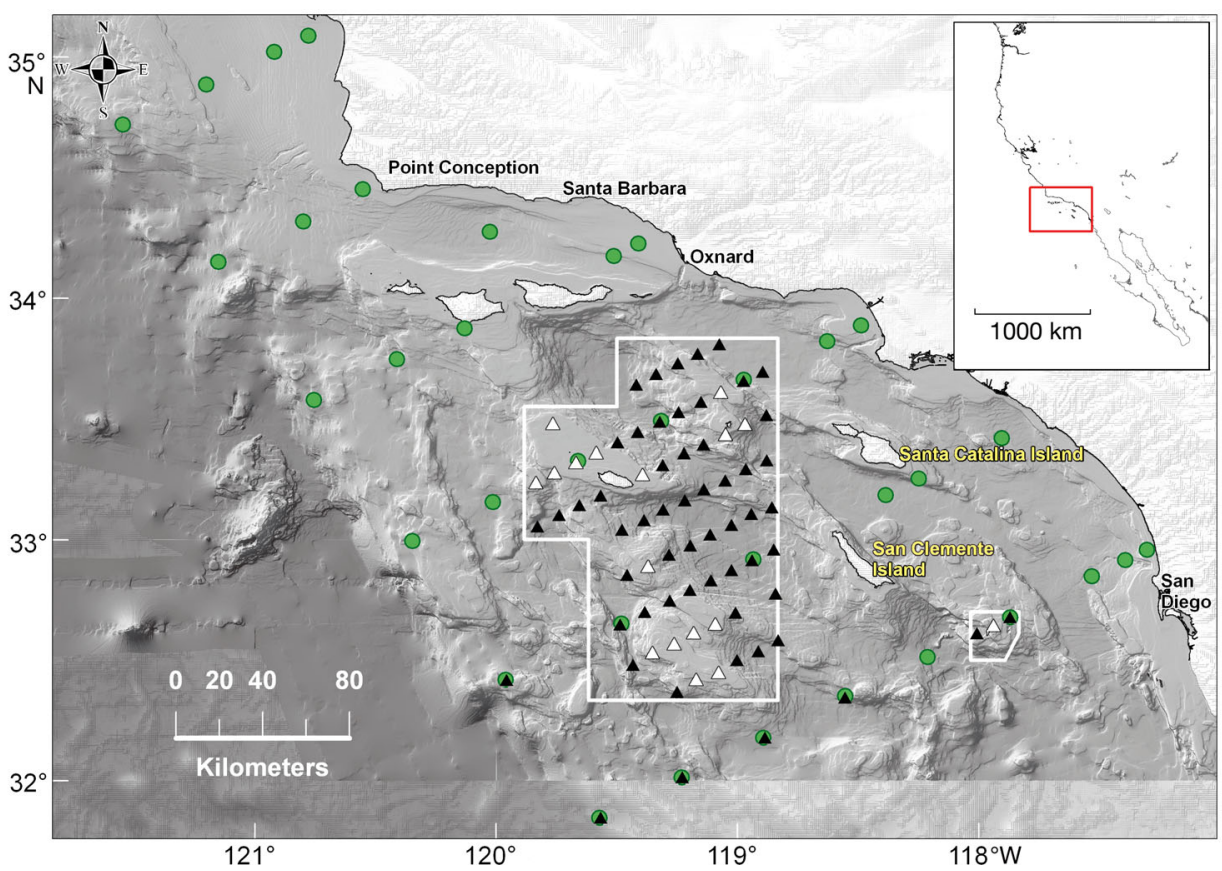

Fig. 1. Location of sampling stations for collection of boccacio larvae in the Cowcod Conservation Area (CCA) for this study; and of ichthyoplankton in the wider area of the Southern California Bight (SCB) by winter California Cooperative Oceanic Fisheries Investigations (CalCOFI) cruises. Samples were collected annually from 2002 to 2004 . ( $\triangle$ ) Sampling stations from CCA cruises within potential spawning habitat $(\mathrm{PSH}) \quad(<300 \mathrm{~m}$ depth); ( $\mathbf{\Delta})$ CCA sampling stations outside PSH (>300 m depth): (0) CalCOFI sampling stations. White lines indicate CCA boundaries 
the abundance of larvae within and around the reserve.

Two factors complicate the identification of spawning locations through larval sampling. First, because currents can advect larvae from natal locations, the distribution of all sampled larvae may not accurately reflect spawning sites. To overcome this challenge, we aged bocaccio larvae and separately evaluated the distribution of recently hatched (mean age $0.6 \mathrm{~d}$ ), preflexion (mean age $5 \mathrm{~d}$ ), and flexion/postflexion (mean age $16 \mathrm{~d}$ ) larvae. We then tested the hypotheses that recently hatched larvae, but not older stages, are associated with potential spawning habitat (PSH), one component of essential fish habitat. We defined PSH as locations with depths $<300 \mathrm{~m}$, based on depth preferences of adult (potentially fecund) bocaccio that are rarely found deeper than $300 \mathrm{~m}$ and tend to associate with or near high relief rocky substrate (Yoklavich et al. 1996, Love et al. 2002). Second, even if spawning stock biomass remains constant, larval output can be affected by variability in oceanographic conditions (Thompson et al. 2012). The oceanography within the SCB is dominated by the California Current System which includes the California Current, a well-described southward surface current located along the SCB shelf break that brings relatively cold, northern Pacific water to the region; and the Southern California Countercurrent, a northward surface current that flows near the coast, with relatively warm, salty water. The Southern California Countercurrent does not always flow continuously around Point Conception to the north (Fig. 1), but instead, together with the California Current, forms a basin-scale gyre known as the Southern California Eddy (Lynn \& Simpson 1987). Below the surface, circulation is dominated by the California Undercurrent, a northward current located over the continental slope between 100 and $300 \mathrm{~m}$ depth (Hickey 1979, Hickey et al. 2003). In general, circulation patterns are seasonally driven and follow surface winds; the Southern California Eddy strengthens during the spring through summer, and the strongest currents are observed during the summer (Hickey 1979, Lynn \& Simpson 1987, DiLorenzo 2003). Coastal winds, islands and bathymetric features, however, introduce variability to the larger-scale SCB circulation (Hickey 1993, Owen 1980), and oceanographic conditions (currents, chlorophyll $a$, temperature, etc.) may be further impacted by interannual changes due to El Niño events (Bograd \& Lynn 2003). Given that sea surface temperature, chlorophyll $a$, and ocean currents are known to influence bocaccio early life history dynamics (Moser et al. 2000, Tolimieri \&
Levin 2005, Zabel et al. 2011), measurement of oceanographic conditions during larval sampling is necessary to contextualize potential changes in larval presence or abundance. This study presents an analysis of samples collected in 3 consecutive years (2002 to 2004) following the establishment of the CCA to evaluate how variability in oceanographic conditions affected larval dynamics. Because bocaccio take at least 5 yr to mature, this analysis should provide insight on baseline reserve conditions rather than directly reflect reserve effects. As such, in this study we determined: (1) if the CCA is located in a region that protects essential bocaccio spawning habitat, (2) the environmental parameters that define spawning habitat, (3) whether older-stage larvae continue to associate with spawning habitat or are advected from these locations, and (4) how interannual oceanographic variability influences bocaccio larval dynamics.

\section{MATERIALS AND METHODS}

\section{Bocaccio life history}

Bocaccio range from the Alaskan peninsula to central Baja California (Love et al. 2002). Bocaccio, like most rockfish, are ovoviviparous and bear live young. Copulation takes place from September to October (Field et al. 2010). Off southern California, peak spawning occurs in January and February (Moser et al. 2000). After parturition, larval bocaccio are approximately 4.0 to $5.0 \mathrm{~mm}$ long (Moser 1996), and typically occur in the upper $100 \mathrm{~m}$ of the water column (Ahlstrom 1959, Lenarz et al. 1991, Ross \& Larson 2003). Juveniles usually settle to demersal, nearshore rocky areas by $3.5 \mathrm{mo}$, before gradually moving to deeper, offshore habitats (Love et al. 2002, Tolimieri \& Levin 2005, Zabel et al. 2011). Adults are found to depths of approximately $500 \mathrm{~m}$ but are most common between 50 and $250 \mathrm{~m}$ where they associate with complex rocky reef substrate (Love et al. 2002).

\section{Sample collection}

Boccacio larvae in the CCA were sampled by oblique bongo net tows $(71 \mathrm{~cm}$ diameter bongo frames equipped with $505 \mu \mathrm{m}$ mesh nets, detachable $333 \mu \mathrm{m}$ mesh cod ends, and a flowmeter) to a depth of $212 \mathrm{~m}$ or $15 \mathrm{~m}$ from the bottom in shallow areas, following standard California Cooperative Oceanic Fisheries Investigations (CalCOFI) protocols (Kramer 
et al. 1972, Moser \& Smith 1993) in 2002 (CCA cruise 0202NH, 8-15 Feb), 2003 (CCA cruise 0302SP, 4-9 Feb), and 2004 (CCA cruise: 0402NH, 10-16 Feb). In total, 73 stations were sampled inside and immediately outside the CCA each year (Fig. 1). Contents of the port side bongo net were preserved in $95 \%$ ethanol while those from the starboard net were preserved in $5 \%$ formalin. Larvae were sorted in the laboratory and identified as bocaccio based on morphological characteristics (Moser 1996). Count data for bocaccio were converted to abundance and expressed as the number of larvae under $10 \mathrm{~m}^{2}$ surface area by multiplying the larval count by the standard

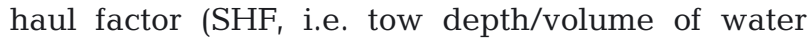
filtered $\times 10$ ) following standard CalCOFI data processing protocol (Smith \& Richardson 1977).

In addition, ichthyoplankton samples were collected during winter CalCOFI cruises. In this case, 35 stations over the continental shelf (Fig. 1) were sampled throughout and just north of the SCB immediately preceding collection of CCA samples (CalCOFI cruises 0201JD, 24 Jan-9 Feb 2002; 0302JD, 30 Jan -15 Feb 2003; 0401JD, 5-20 Jan 2004. See Hewitt 1988 for description of CalCOFI sampling regime). Boccacio larvae collected by these cruises provide the sample frames for comparative analysis of boccacio larvae collected in the CCA versus the SCB as a whole (see 'Analyses' subsection, below).

We also measured 4 environmental parameters (sea surface temperature, chlorophyll $a$, depth, and ocean currents) that previous studies suggest impact rockfish during their pelagic larval phase (Moser et al. 2000, Taylor et al. 2004, Doyle et al. 2009, Zabel et al. 2011) and could therefore potentially account for patterns in larval distribution and abundance. Sea surface temperature and depth were recorded concurrently with ichthyoplankton sampling at each station $(\mathrm{N}=73)$. Averaged near-surface chlorophyll $a$ at a $1.5 \mathrm{~km}$ resolution for the $30-\mathrm{d}$ period centered on the CCA survey dates in 2002 to 2004 ( $\mathrm{N}=66$ ) were obtained from the National Aeronautics and Space Administration Sea-viewing Wide Field-of-View Sensor (SeaWIFS, seawifs.gsfc.nasa.gov). Chlorophyll a data derived by SeaWIFS are known to be highly correlated $\left(\mathrm{r}^{2}=0.90-0.93\right)$ with chlorophyll $a$ values measured during CalCOFI cruises (Kahru \& Mitchell 1999).

Ocean currents were estimated from acoustic Doppler current profiler (ADCP) data collected during the winter CalCOFI cruises that were conducted within or around the same time periods as the CCA sampling. The CalCOFI cruises traversed the CCA while sampling the SCB and offshore waters each year, but only data collected within the CCA were analyzed for this study. Upper ocean currents were measured continuously along the ship track from a hullmounted $150 \mathrm{kHz}$ narrowband ADCP (Teledyne RD Instruments) configured to transmit an $8 \mathrm{~m}$ pulse $\mathrm{s}^{-1}$ along 4 beams directed downwards at $30^{\circ}$ with respect to vertical. Data were obtained from the National Oceanographic Data Center as ASCII files, after being processed into hourly and $10 \mathrm{~min}$ intervals. Given that near-inertial motions are largest within the surface layer and may generate noise in the data (Taylor et al. 2004), currents were averaged vertically between 20 and $80 \mathrm{~m}$, which corresponds both to the average depth of the thermocline (Hitchman 2011) and the vertical range of larval bocaccio (Lenarz et al. 1991). Additionally, tidal motions were removed using a 40h Butterworth low-pass filter (Emery \& Thomson 2001). Currents were separated into V (north-south) and $U$ (east-west) components, and were averaged to calculate net flow inside the CCA.

\section{Ageing and staging of larvae}

Previous studies demonstrated that Sebastes spp. larvae can be aged by direct enumeration of daily otolith increments (Penney \& Evans 1985, Laidig et al. 1991, Ralston et al. 1996), and otoliths and body growth in many fishes are proportional (Ralston 1976, Penney \& Evans 1985). Hence, age-to-length relationships can be used to estimate the age of larval rockfish when otoliths are not available.

Total length for all CCA larvae was measured to the nearest $0.1 \mathrm{~mm}$. To age the larvae, both sagittae, when possible, were extracted from ethanol-preserved samples; this procedure was followed for samples from $2002(\mathrm{~N}=81)$ and $2003(\mathrm{~N}=93)$. Otoliths were placed on slides, covered with a drop of immersion oil, and viewed at $650 \times$ magnification with a compound microscope equipped with an Olympus MagnaFire SP digital camera and software. Only fish with a dark check mark (i.e. extrusion check) which encircled the primordium were used in the analysis (see Penney \& Evans 1985, Laidig \& Ralston 1995). Fish with this mark and no additional increments were given a nominal age of zero. Additional increments beyond the extrusion check were counted along the longest axis to determine larval age. All counts were made twice. In instances where counts differed, a third count was conducted using the same procedure to determine which count was correct.

Larvae were separated into 3 categories following Moser (1996): recently hatched, preflexion, and 
flexion/postflexion (flexion typically commences at $\sim 7 \mathrm{~mm}$ and, due to low sample size, we grouped flexion and postflexion larvae into a single category). Using the otolith ageing data, fish $<2 \mathrm{~d}$ old were placed into the recently hatched category. Preflexion and postflexion categories were determined by examining the degree of flexion of the terminal section of the notochord during formation of the caudal fin (Moser 1996).

Otolith ageing of bocaccio larvae in 2004 was not possible due to logistical constraints, as only samples preserved in formalin were available. Therefore, we used linear regression and followed standard otolith analysis methods (Ralston 1976, Ralston et al. 1996, Ralston \& MacFarlane 2010) to determine the relationship between age and length using the 2002 and 2003 data. This age-length regression was used to determine age of larvae from formalin samples, particularly to assign larvae to the recently hatched category (Hitchman 2011). Because a majority (87\%) of larvae $\leq 4.2 \mathrm{~mm}$ were $\leq 1 \mathrm{~d}$ old, based on the 2002 and 2003 surveys (see 'Results'), all 2004 larvae $\leq 4.2 \mathrm{~mm}$ were categorized as recently hatched. All larvae $>4.2 \mathrm{~mm}$ were staged based on notochord flexion. A comparison of length-frequency distributions of ethanol- and formalin-preserved larvae from the 2002 and 2003 CCA surveys showed little difference in size structure attributable to preservation method (Ralston \& MacFarlane 2010).

\section{Analyses}

Larval bocaccio and environmental data from the CCA were integrated into Geographical Information System (ArcGIS ArcMap version 9.3, Esri) for processing, visualization, and analysis. Bathymetry data for the SCB were obtained from the National Geophysical Data Center and contour lines were constructed from the bathymetry layer using the Surface Analysis tool under Spatial Analyst. To map the distributions of larval bocaccio, each age class (recently hatched, preflexion, postflexion) was imported into ArcMap as point data using a NAD 1983 projection.

To determine whether bocaccio larvae were more likely to be found in the CCA relative to wider continental shelf waters in Southern California, we used logistic regression to compare the proportion of sample stations where bocaccio were present in the CCA versus the CalCOFI sample frames. In this analysis, we excluded 5 stations from the CCA that were outside of reserve bounds and, due to the low number of stations containing bocaccio in CalCOFI samples, combined larvae from all size classes. We conducted separate analyses for 2002, 2003, and 2004. All statistical analyses were performed with R Version 2.15.0 (R Development Core Team 2010).

Next, we analyzed the distribution of larval bocaccio using the 73 stations sampled during the CCA cruises, and hypothesized that recently hatched larvae would associate with PSH (i.e. locations with depths $<300$ m; Fig. 1) but that older stages would be advected from natal habitat and show no association with PSH. We again used logistic regression to model the probability of the presence of recently hatched larvae against the presence-absence of PSH. Because postflexion larvae were scarce in 2002 and 2003, we only performed tests on fishes in this stage in 2004. Logistic regression was selected as the main statistical tool to evaluate bocaccio distribution because the high number of zero-count samples precluded the use of models that assume a normal, poisson or negative binomial distribution, and the relatively low number of samples compromised the efficacy of 2 component (e.g. delta-glm, hurdle) approaches (Quinn \& Keough 2002). To discern whether lack of independence among samples potentially biased results we tested for spatial autocorrelation in the residuals of each model by evaluating the significance of global Moran's I (Dormann et al. 2007). If global Moran's $I$ was significant at $\alpha=0.05$, we used autologistic regression to evaluate the significance of PSH on the presence of stage-specific bocaccio. Autologistic regression includes an additional covariate (i.e. autocovariate) in a binomial model that captures the spatial structure of neighboring dependent variables (Augustin et al. 1996). We then recalculated global Moran's $I$ values to determine if there was significant autocorrelation in the residuals of the autologisitic models and reported slope estimates from the autologistic models to discern whether PSH affected the presence/absence of stage-specific larvae. Spatial modeling was conducted using the $\mathrm{R}$ package spdep (Bivand 2012).

To evaluate in greater detail factors that affect stage-specific larval bocaccio distribution, we assessed the relative plausibility of 7 a priori candidate logistic regression models that included linear combinations of 3 environmental parameters (sea surface temperature, depth, and chlorophyll a) to explain the probability of occurrence of recently hatched and preflexion larvae in all years, and postflexion larvae in 2004. We first checked for colinearity among the independent variables and chose to retain each covariate as $R^{2}$ values were consistently low $(<0.35)$ for pairwise correlations (Table S1 in the supplement at 
www.int-res.com/articles/suppl/m465p227_supp.pdf). We tested each set of candidate models for each year to determine the consistency of potentially important variables. We used Akaike's Information Criterion adjusted for small sample sizes $\left(\mathrm{AIC}_{\mathrm{C}}\right)$ to assess the relative importance of each model within a set of candidate models (Burnham \& Anderson 2002). For each model, we calculated $\Delta \mathrm{AIC}_{\mathrm{C}}$ and Akaike weight $\left(w_{i}\right)$ as measures of the relative performance of the competing models (Burnham \& Anderson 2002). We computed model-averaged parameter estimates and $90 \%$ confidence intervals around these estimates for each predictor variable of interest among a set of candidate models weighted by $w_{i}$ values (Burnham \& Anderson 2002) with the R package AICcmodavg (Mazerolle 2011). We interpreted as significant parameters with confidence intervals that did not overlap zero (Burnham \& Anderson 2002). As for analyses involving PSH (see above), we tested for spatial autocorrelation in the residuals of the most plausible model from each group of candidate models, and incorporated an autocovariate into a set of candidate models if there was significant spatial autocorrelation. We then recalculated slope estimates and confidence intervals using an autologistic model. To help interpret the relative contribution of each covariate on stage-specific bocaccio presence, we present slope estimates using both original and normalized [(value-mean)/standard deviation] independent variables.

\section{RESULTS}

The probability of bocaccio larval presence was significantly higher in the CCA than in the SCB as a whole (CalCOFI samples) in each sample year (Table 1). Specifically, bocaccio larvae were detected in 38,56 , and $74 \%$ of CCA stations in 2002,2003 , and

Table 1. Sebastes paucispinis. Logistic models of presence of bocaccio larvae in the Cowcod Conservation Area (CCA) in 2002 to 2004, versus their presence in the wider Southern California Bight (SCB) covered by California Cooperative Oceanic Fisheries Investigations (CalCOFI) surveys. A positive slope indicates that the probability of detecting larvae was higher in the CCA than the CalCOFI area. LCI and UCI are lower and upper $90 \%$ confidence intervals, respectively; the $p$-value was assessed at $\alpha=0.05$

\begin{tabular}{|ccccc|}
\hline Year & Slope $_{\text {CCA }}$ & LCI & UCI & p-value \\
\hline 2002 & 1.35 & 0.66 & 2.08 & $<0.002$ \\
2003 & 1.83 & 0.66 & 2.08 & $<0.0001$ \\
2004 & 3.14 & 2.40 & 3.98 & $<0.0001$ \\
\hline
\end{tabular}

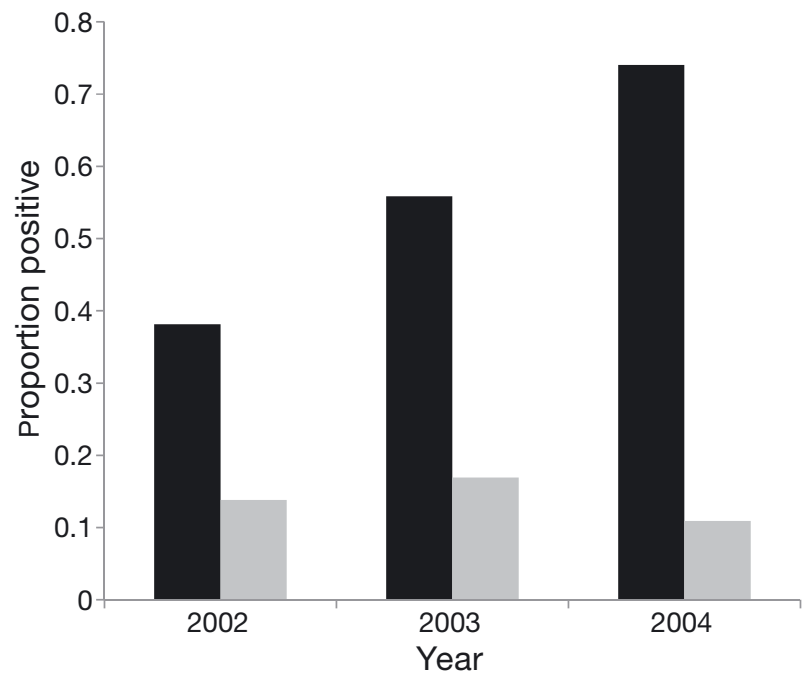

Fig. 2. Sebastes paucispinis. Proportion of stations in the Cowcod Conservation Area (CCA) (black bars) versus the California Cooperative Oceanic Fisheries Investigations (CalCOFI) sample frame (gray bars) where bocaccio larvae were detected in 2002 to 2004

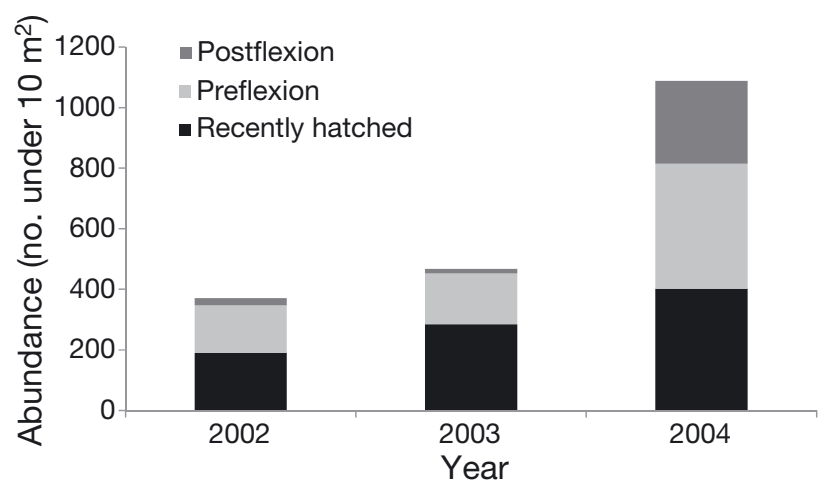

Fig. 3. Sebastes paucispinis. Total larval abundance in the Cowcod Conservation Area (CCA) by age class during 2002 to 2004

2004, respectively. By contrast, larvae were found in only 14,17 , and $11 \%$, respectively, of CalCOFI stations during these same years (Fig. 2).

Otolith ageing indicated that although there were ontogenetic decreases in the relative abundance of bocaccio between the recently hatched and preflexion stages in $2002(-17 \%)$ and $2003(-41 \%)$, there was a slight increase in preflexion larvae relative to recently hatched larvae in 2004 (+3\%) (Fig. 3). In all years, the relative abundance of postflexion larvae was less than that of preflexion larvae $(-85,-91$, and $-33 \%$ in 2002, 2003, and 2004, respectively). Mean size and length ranges varied for all ages between 2002 and 2003, but recently hatched larvae were never $>5.1 \mathrm{~mm}$ (Table $\mathrm{S} 2$ in the supplement).

Although PSH comprised less than $13 \%$ of the CCA study area, over $60 \%$ of recently hatched larvae 


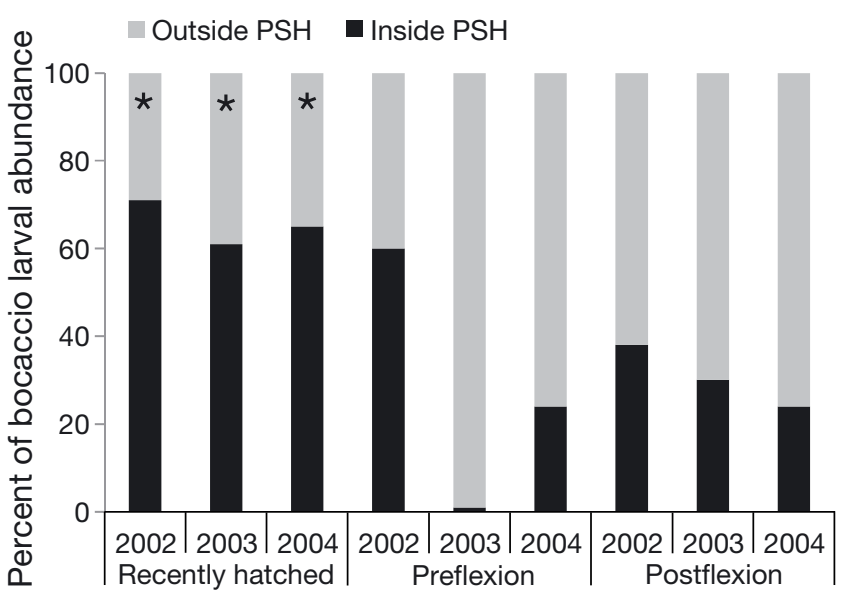

Fig. 4. Sebastes paucispinis. Percent of larval bocaccio abundance inside potential spawning habitat $\left(\mathrm{PSH}_{i}<300 \mathrm{~m}\right.$ depth) and outside PSH (>300 m) for each age class. (*) Age class significantly associated with PSH at $\mathrm{p}<0.05$

were found at PSH stations each year (Fig. 4). Further, logistic regression revealed a significant, positive relationship between the probability of observing a recently hatched larva and the presence of PSH in each year (Table 2). Significant spatial autocorrelation based on global Moran's I was only detected in the residuals of the model of recently hatched larvae in 2004 (Table S3 in the supplement), and the relationship with PSH remained significant after inclusion of an autocovariate term (Tables $2 \&$ S3). The

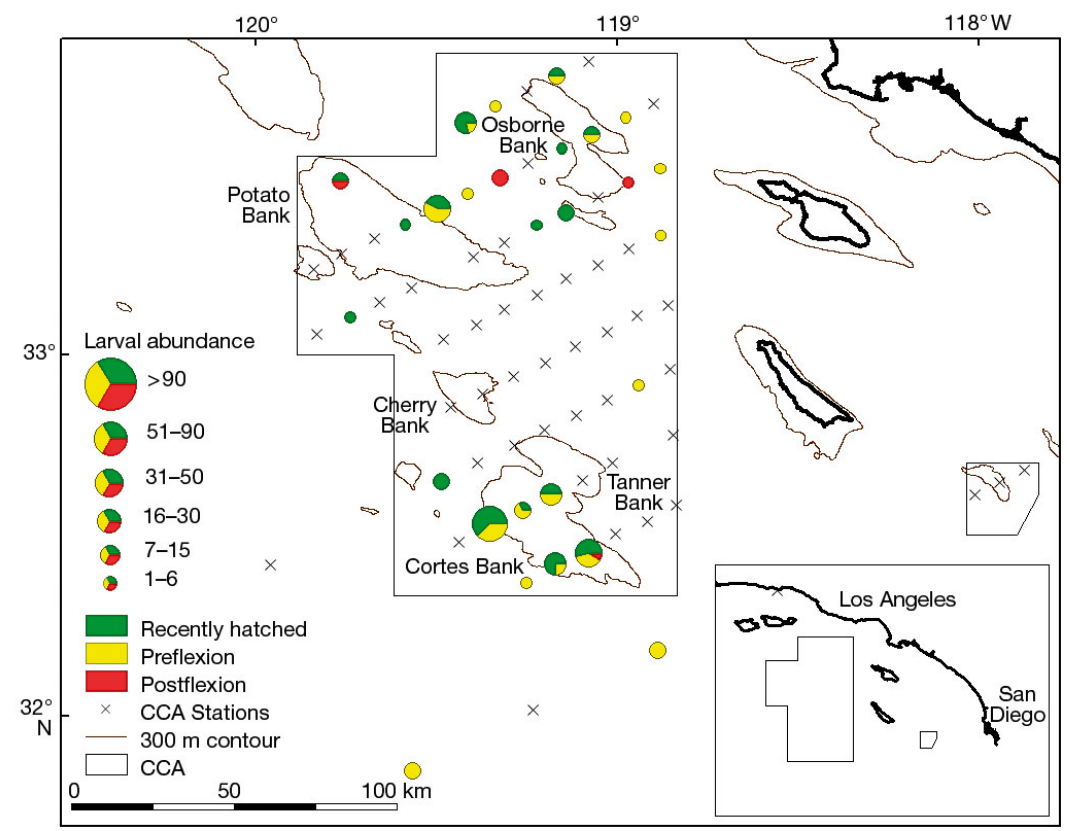

Fig. 5. Sebastes paucispinis. Distribution of bocaccio larvae in the Cowcod Conservation Area (CCA) by age class in 2002. Size of circles indicates larval abundance (no. of larvae under $10 \mathrm{~m}^{2}$ surface area) at each station. $(x)$ Sampling station where no bocaccio were collected
Table 2. Sebastes paucispinis. Logistic models of the presence of recently hatched $(\mathrm{RH})$, preflexion $(\mathrm{PF})$ and postflexion (PO) bocaccio larvae within potential spawning habitat (PSH) in the Cowcod Conservation Area (CCA) in 2002 to 2004, versus the presence of larvae outside PSH. A positive slope indicates probability of larval presence increases if a station is within PSH. An autocovariate term was included in the 2004 RH model because significant spatial autocorrelation was found in residuals of the non-spatial model. LCI and UCI are lower and upper $90 \%$ confidence intervals, respectively; the $p$-value was assessed at $\alpha=0.05$

\begin{tabular}{|lrrrc|}
\hline Dependent variable & Slope $_{\mathrm{PSH}}$ & LCI & UCI & p-value \\
\hline $2002 \mathrm{RH}$ & 1.69 & 0.68 & 2.73 & 0.01 \\
$2002 \mathrm{PF}$ & 0.72 & -0.30 & 1.70 & 0.24 \\
$2003 \mathrm{RH}$ & 2.76 & 1.72 & 3.94 & $<0.0001$ \\
$2003 \mathrm{PF}$ & -2.03 & -4.34 & -0.56 & 0.06 \\
$2004 \mathrm{RH}$ & 1.55 & 0.51 & 2.72 & 0.02 \\
$\quad$ (autologistic model) & & & & \\
2004 PF & -0.05 & -0.97 & 0.87 & 0.93 \\
$2004 \mathrm{PO}$ & -0.39 & -1.37 & 0.54 & 0.50 \\
\hline
\end{tabular}

percentage of larvae over PSH decreased by stage from recently hatched to preflexion for all years (Fig. 4), and there was no significant relationship between PSH and presence of older-stage larvae in any year ( $p$ > 0.05). Notably, there was a nearly significant, negative relationship between PSH and preflexion larvae in 2003 ( $\mathrm{p}=0.06$; Table 2).

Total larval abundance from the CCA cruises increased during each study year with 2004 abundances approximately 2.9 and 2.3 times greater than in 2002 and 2003, respectively (Fig. 3). In 2002, recently hatched larvae were found between Potato and Osborne Banks with highest abundances centered over Tanner and Cortes banks (Fig. 5). Preflexion larvae were dispersed in the northern and southern portions of the study area, and the majority of postflexion larvae were in the northern CCA (Fig. 5). In 2003, recently hatched larvae were concentrated inside the 300 $\mathrm{m}$ depth contour throughout the CCA but were particularly abundant in western Potato, Cherry, Tanner, and Cortes banks (Fig. 6). Preflexion larvae were distributed northeast of the banks in the CCA, and postflexion larvae were only found near Tanner and Cortes banks (Fig. 6). The highest overall bocaccio abundance occurred in 2004, which was reflected by increases in abundance of each 
age class (Fig. 3). Similarly to 2002 and 2003, recently hatched larvae in 2004 were most abundant inside the $300 \mathrm{~m}$ depth contour within the CCA, but most concentrated near western Cherry Bank (Fig. 7). In 2004, pre- and postflexion larvae were widely distributed throughout the CCA, especially when com-

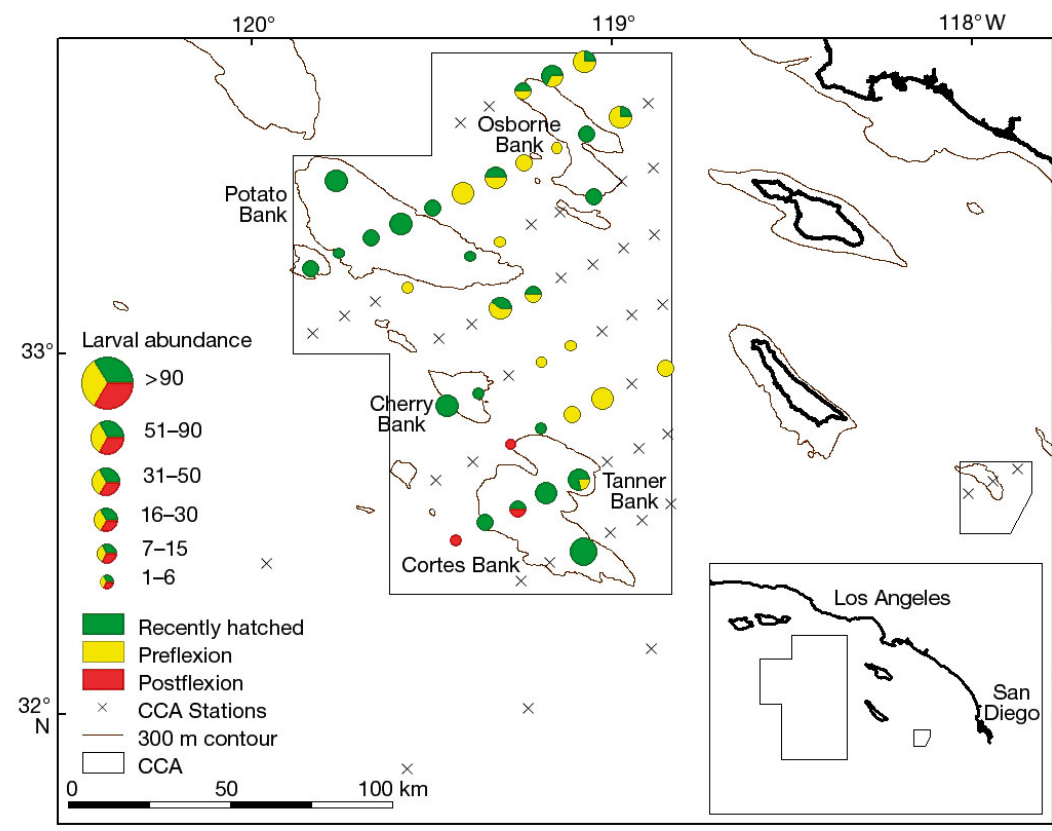

Fig. 6. Sebastes paucispinis. Distribution of bocaccio larvae in the Cowcod Conservation Area (CCA) by age class in 2003. See Fig. 5 legend for explanation of symbols

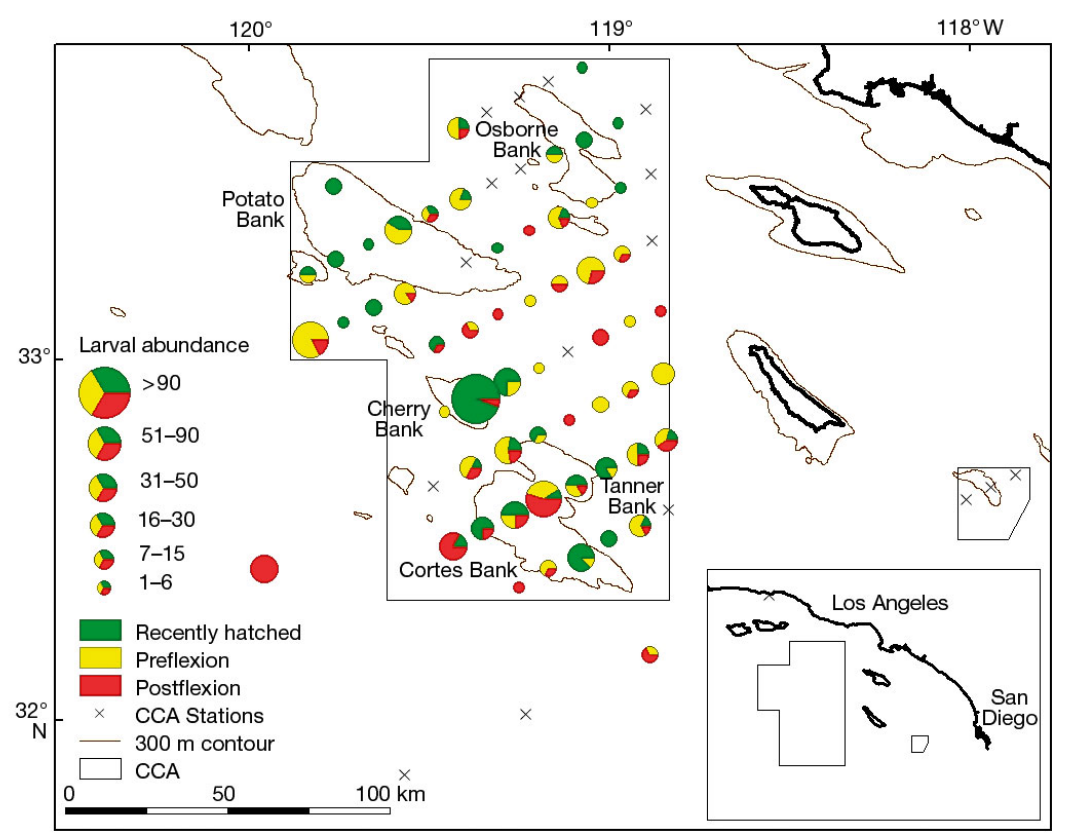

Fig. 7. Sebastes paucispinis. Distribution of bocaccio larvae in the Cowcod Conservation Area (CCA) by age class in 2003. See Fig. 5 legend for explanation of symbols pared to postflexion distributions in the previous 2 years (Figs. 5 to 7 ).

Sea surface temperature in the CCA fluctuated amongst years. Mean sea surface temperature increased by $1.0^{\circ} \mathrm{C}$ between 2002 and 2003 and then decreased by $1.2^{\circ} \mathrm{C}$ from 2003 to 2004 (Table 3, Fig. 8).

Spatially, temperatures were lower in the northwestern CCA with coolest temperatures reaching Potato Bank in 2002 and 2003, but extending southward to northern Tanner and Cortes banks in 2004 (Fig. 8). The eastern CCA was characterized by warmer temperatures (around Osborne Bank: Fig. 8).

Satellite-derived chlorophyll a data were compared with the annual 'state of the California Current' reports (2002: Schwing et al. 2002; 2003: Venrick et al. 2003; 2004: Goericke et al. 2004) and matched overall chlorophyll a patterns obtained from CalCOFI cruises. Mean chlorophyll a displayed an opposite pattern to sea surface temperature patterns, as values decreased by $0.1 \mathrm{mg} \mathrm{m}^{-3}$ from 2002 to 2003 and then increased by $0.16 \mathrm{mg} \mathrm{m}^{-3}$ from 2003 to 2004 (Table 3, Fig. 9). During each year, chlorophyll a concentrations were highest in the northwestern CCA near Potato Bank, but extended eastward to Osborne Bank and southward near Cherry Bank in 2004 (Fig. 9C).

In 2002, ocean currents inside the CCA predominantly flowed towards the northwest (Table 3) with the exception of the area west-northwest of Cortes Bank where currents were reversed (Fig. 10A). In 2003, net flow inside the CCA was toward the northeast (Table 3); however, flow direction appeared cyclonic over the $\sim 200 \mathrm{~km}$ scale study area with westward currents over Osborne Bank and southeastward currents offshore of Potato Bank (Fig. 10B). Net current flow in 2004 was southwestward (Table 3) but currents were spatially more variable than in previous years, particularly between Potato and Osborn Banks where flow was in all directions, and south of Cherry Bank where currents flowed more uniformly toward the south-southeast (Fig. 10C). 
Table 3. Summary of mean values $( \pm \mathrm{SD})$ for sea surface temperature (SST) and chlorophyll $a$ in the Cowcod Conservation Area (CCA) in 2002 to 2004. Current components ( $V$ : north-south; $U$ : east-west) were averaged to thermocline depth to calculate net current flow within the CCA where bocaccio larvae are found within the water column. Ranges are shown in parentheses

\begin{tabular}{|ccccc|}
\hline \multirow{2}{*}{ Year } & & & \multicolumn{2}{c|}{ Currents } \\
\cline { 4 - 5 } 2002 & $14.15 \pm 0.54$ & $0.53 \pm 0.20$ & 2.26 & $U\left(\mathrm{~cm} \mathrm{~s}^{-1}\right)$ \\
\hline \multirow{2}{*}{2003} & $(13.1,15.4)$ & $(0,1.3)$ & $(-5.01,1.49)$ & $(1.91,5.62)$ \\
& $15.16 \pm 0.61$ & $0.43 \pm 0.14$ & 1.93 & 1.02 \\
& $(12.5,16.7)$ & $(0.1,0.72)$ & $(-1.88,8.01)$ & $(-1.99,5.44)$ \\
2004 & $13.97 \pm 0.53$ & $0.59 \pm 0.13$ & -2.22 & -1.99 \\
& $(12.7,15.0)$ & $(0.13,0.72)$ & $(-14.65,11.54)$ & $(-12.34,11.11)$ \\
\hline
\end{tabular}

cently hatched larvae (Table 4). Preflexion larvae were not strongly affected by any of the covariates in 2002 or 2004 but positively related with depth and chlorophyll a in 2003 (Table 4). As opposed to recently hatched larvae, normalized slope estimates for 2003 preflexion larvae were the same for depth and chlorophyll a (Table 4). In 2004, when postflexion larvae were sufficiently abundant to conduct statistical analyses, there was a negative relationship between chlorophyll $a$ and the probability of larval bocaccio presence (Tables 4 \& S6). Significant (global Moran's $I, \mathrm{p}<0.05)$ spatial autocorrelation was detected in the residuals of the best models for recently hatched and postflexion larvae in 2004 (Table S7). After inclusion of an autocovariate term, however, residual spatial autocorrelation was not significant $(\mathrm{p}>0.05)$. To correct for spatial autocorrelation, slope estimates for recently hatched and postflexion larvae in 2004 were based on autologistic models (Table 4).
Model selection (Tables S4-S6 in the supplement) and averaging (Table 4) indicated that the probability of presence of recently hatched larvae was negatively related with depth during each year, positively related with chlorophyll $a$ in 2002 and 2003, and negatively related with sea surface temperature in 2004 (Tables 4 \& S4-S6). Comparison of slopes based on normalized covariates suggested that depth was consistently the most important variable influencing re-

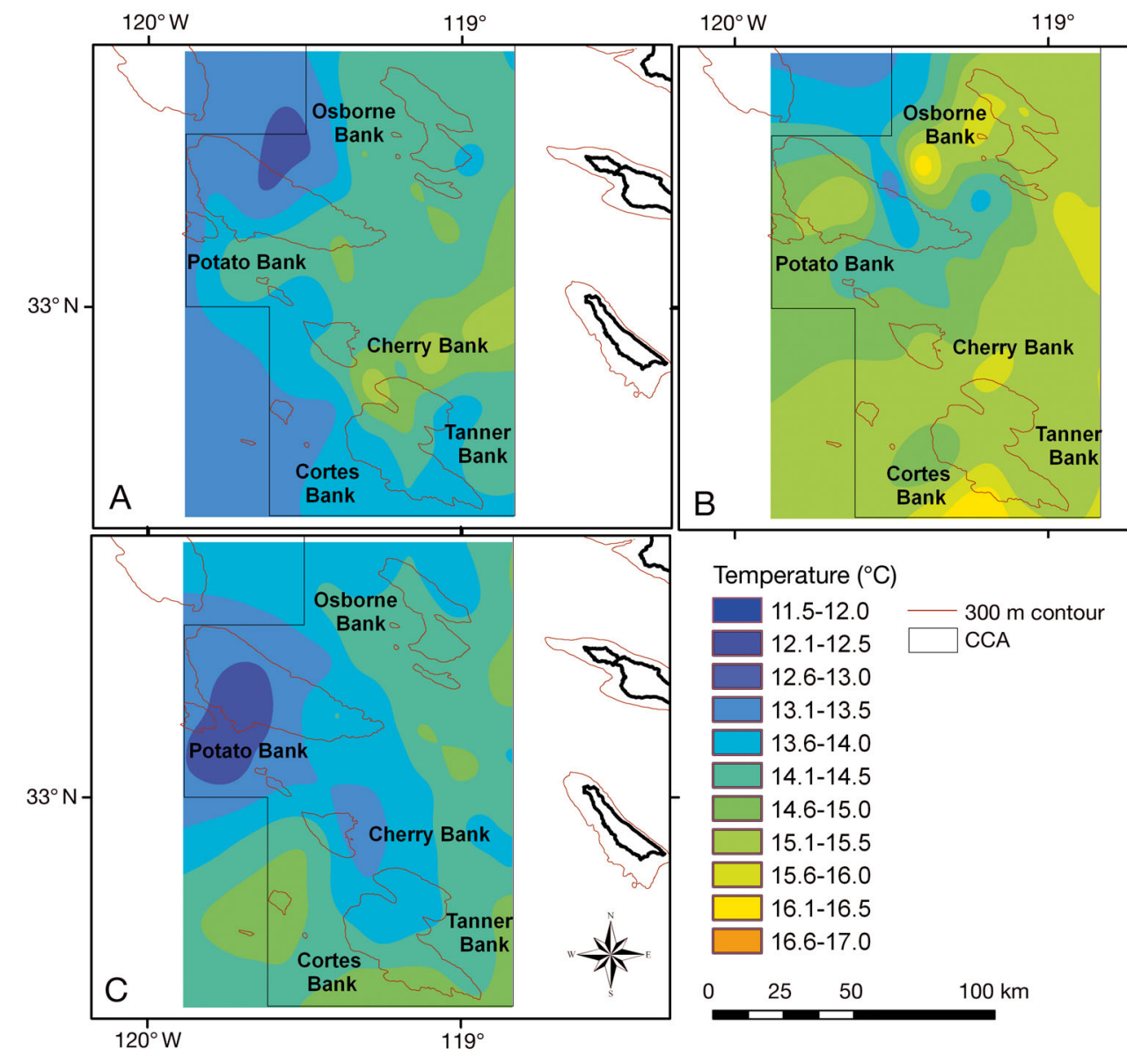

Fig. 8. Sea surface temperature in Cowcod Conservation Area (CCA) during (A) 2002, (B) 2003, and (C) 2004. Eastern CCA (where no larvae were found) is not shown 

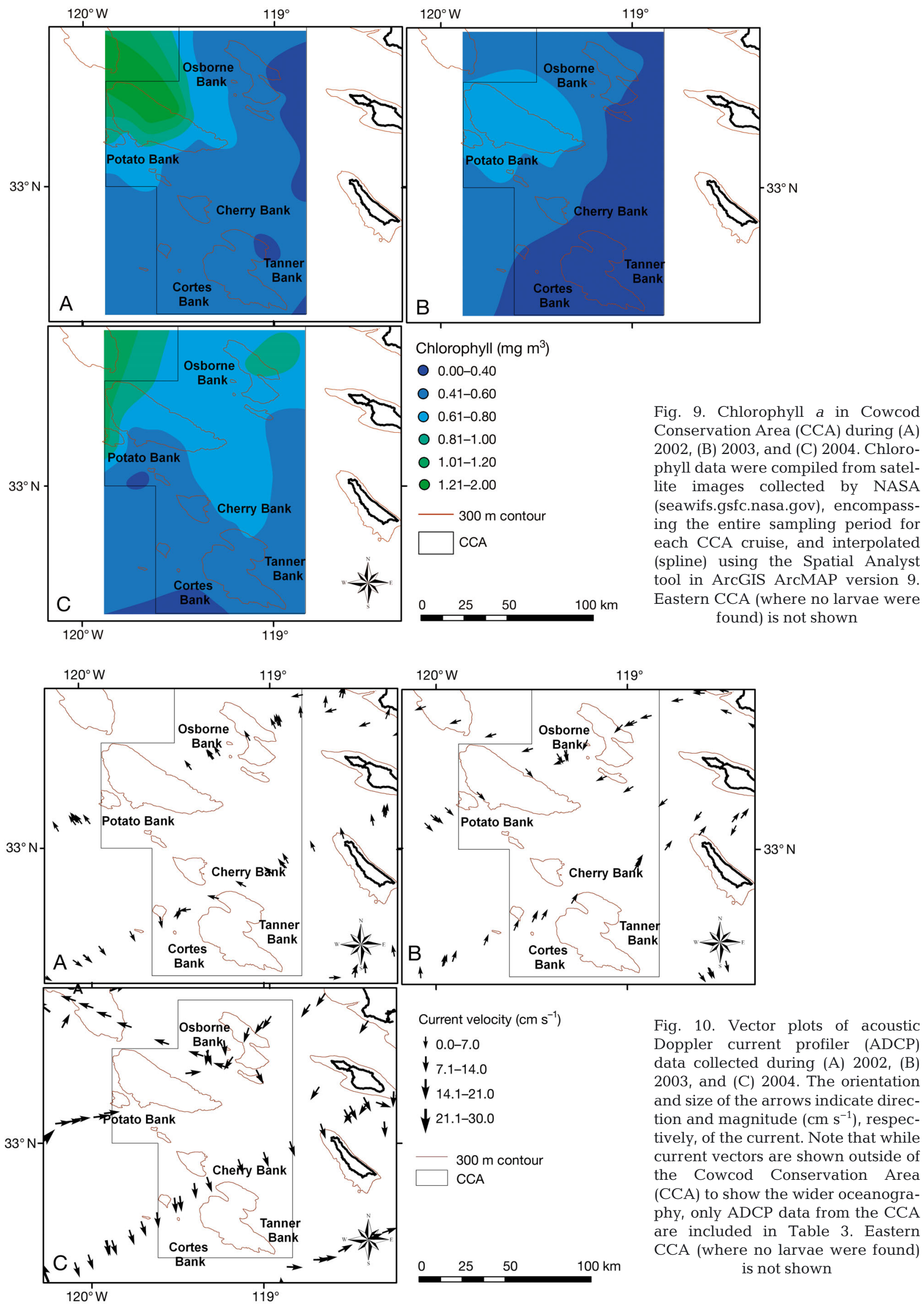

Fig. 10. Vector plots of acoustic Doppler current profiler (ADCP) data collected during (A) 2002, (B) 2003, and (C) 2004. The orientation and size of the arrows indicate direction and magnitude $\left(\mathrm{cm} \mathrm{s}^{-1}\right)$, respectively, of the current. Note that while current vectors are shown outside of the Cowcod Conservation Area (CCA) to show the wider oceanography, only ADCP data from the CCA are included in Table 3. Eastern CCA (where no larvae were found) is not shown 
Table 4. Sebastes paucispinis. Model-averaged parameter estimates and lower and upper $90 \%$ confidence intervals (LCI and UCI respectively) for models of environmental covariates (depth, sea surface temperature [SST] and chlorophyll a) against larval stage (RH: recently hatched; PF: preflexion; PO: postflexion). Parameters in bold font depict covariates with $90 \%$ confidence intervals that do not overlap zero. Estimates based on original covariates used data in original units (e.g. meters for depth) while those with normalized covariates used data where values were subtracted from the mean and divided by the standard deviation. Autologistic models included a spatial autocovariate to account for spatial autocorrelation in the residuals. The $p$-value was assessed at $\alpha=0.05$

\begin{tabular}{|c|c|c|c|c|c|c|c|}
\hline \multirow[b]{2}{*}{ Dependent variable } & \multirow[b]{2}{*}{ Parameter } & \multicolumn{3}{|c|}{ Original covariates } & \multicolumn{3}{|c|}{ Normalized covariates } \\
\hline & & Estimate & LCI & UCI & Estimate & LCI & UCI \\
\hline $2002 \mathrm{RH}$ & $\begin{array}{l}\text { Depth } \\
\text { SST } \\
\text { Chl a }\end{array}$ & $\begin{array}{l}-0.0012 \\
-0.60 \\
2.90\end{array}$ & $\begin{array}{c}-0.0022 \\
-1.77 \\
0.34\end{array}$ & $\begin{array}{c}-0.0001 \\
0.58 \\
5.45\end{array}$ & $\begin{array}{r}-0.63 \\
-0.32 \\
0.57\end{array}$ & $\begin{array}{r}-1.21 \\
-0.95 \\
0.07\end{array}$ & $\begin{array}{r}-0.05 \\
0.31 \\
1.08\end{array}$ \\
\hline $2002 \mathrm{PF}$ & $\begin{array}{l}\text { Depth } \\
\text { SST } \\
\text { Chl a }\end{array}$ & $\begin{array}{l}-0.0001 \\
-0.76 \\
-1.34\end{array}$ & $\begin{array}{l}-0.0009 \\
-1.69 \\
-4.11\end{array}$ & $\begin{array}{l}0.0008 \\
0.17 \\
1.43\end{array}$ & $\begin{array}{l}-0.03 \\
-0.41 \\
-0.27\end{array}$ & $\begin{array}{l}-0.50 \\
-0.90 \\
-0.82\end{array}$ & $\begin{array}{l}0.43 \\
0.09 \\
0.28\end{array}$ \\
\hline $2003 \mathrm{RH}$ & $\begin{array}{l}\text { Depth } \\
\text { SST } \\
\text { Chl a }\end{array}$ & $\begin{array}{c}-0.0023 \\
-0.60 \\
5.01\end{array}$ & $\begin{array}{c}-0.0035 \\
-1.59 \\
0.85\end{array}$ & $\begin{array}{c}-0.0012 \\
0.39 \\
9.17\end{array}$ & $\begin{array}{r}-1.28 \\
-0.37 \\
0.69\end{array}$ & $\begin{array}{r}-1.90 \\
-0.97 \\
0.12\end{array}$ & $\begin{array}{r}-0.65 \\
0.24 \\
1.27\end{array}$ \\
\hline $2003 \mathrm{PF}$ & $\begin{array}{l}\text { Depth } \\
\text { SST } \\
\text { Chl a }\end{array}$ & $\begin{array}{l}0.0013 \\
0.81 \\
5.33\end{array}$ & $\begin{array}{c}0.0003 \\
-0.38 \\
0.06\end{array}$ & $\begin{array}{c}0.0024 \\
2.00 \\
10.60\end{array}$ & $\begin{array}{l}0.74 \\
0.49 \\
0.74\end{array}$ & $\begin{array}{r}0.17 \\
-0.23 \\
0.01\end{array}$ & $\begin{array}{l}1.30 \\
1.22 \\
1.47\end{array}$ \\
\hline $\begin{array}{l}2004 \text { RH } \\
\text { (autologistic model) }\end{array}$ & $\begin{array}{l}\text { Depth } \\
\text { SST } \\
\text { Chl a }\end{array}$ & $\begin{array}{l}-0.002 \\
-2.06 \\
-2.39\end{array}$ & $\begin{array}{l}-0.003 \\
-3.30 \\
-6.83\end{array}$ & $\begin{array}{c}-0.001 \\
-0.83 \\
2.05\end{array}$ & $\begin{array}{l}-1.07 \\
-1.09 \\
-0.32\end{array}$ & $\begin{array}{l}-1.63 \\
-1.74 \\
-0.91\end{array}$ & $\begin{array}{r}-0.50 \\
-0.44 \\
0.27\end{array}$ \\
\hline $2004 \mathrm{PF}$ & $\begin{array}{l}\text { Depth } \\
\text { SST } \\
\text { Chl a }\end{array}$ & $\begin{array}{l}0.0001 \\
-0.48 \\
-0.89\end{array}$ & $\begin{array}{l}-0.0006 \\
-1.26 \\
-3.95\end{array}$ & $\begin{array}{l}0.0008 \\
0.30 \\
2.17\end{array}$ & $\begin{array}{r}0.06 \\
-0.25 \\
-0.12\end{array}$ & $\begin{array}{l}-0.34 \\
-0.66 \\
-0.53\end{array}$ & $\begin{array}{l}0.46 \\
0.16 \\
0.29\end{array}$ \\
\hline $\begin{array}{l}2004 \text { PO } \\
\text { (autologistic model) }\end{array}$ & $\begin{array}{l}\text { Depth } \\
\text { SST } \\
\text { Chl a }\end{array}$ & $\begin{array}{l}0.0005 \\
-0.31 \\
-3.78\end{array}$ & $\begin{array}{l}-0.0003 \\
-1.17 \\
-7.28\end{array}$ & $\begin{array}{c}0.0013 \\
0.54 \\
-0.29\end{array}$ & $\begin{array}{r}0.27 \\
-0.17 \\
-0.51\end{array}$ & $\begin{array}{l}-0.15 \\
-0.62 \\
-0.97\end{array}$ & $\begin{array}{r}0.70 \\
0.29 \\
-0.04\end{array}$ \\
\hline
\end{tabular}

\section{DISCUSSION}

All marine fishes require suitable habitats for feeding, growth to sexual maturity, and reproductive success (Gallagher \& Heppell 2010), and identifying these habitats is crucial to ensure effective conservation and fisheries management. A main goal of this study was to determine whether the CCA affords such protection to bocaccio. Although the boundaries of the CCA were established to protect cowcod (Butler et al. 2003), our results suggest that this is a region of high bocaccio productivity relative to Southern California as a whole. The importance of the CCA for bocaccio spawning was also identified during a recent ichthyoplankton-based bocaccio stock assessment (Ralston \& MacFarlane 2010). While spatial analysis of the mean abundance of bocaccio larvae based on CalCOFI stations (Fig. 1) and averaged over a $50 \mathrm{yr}$ period (1955 to 2005) indicated that peak larval abundance was centered near the northern Channel Islands (north of the CCA), anomalies from the long-term average indicate that peak larval abundances were in the CCA in 2002 and 2003 (Ral- ston \& MacFarlane 2010). Although it is unclear why the center of bocaccio spawning shifted to the CCA in recent years (it is unlikely that $1 \mathrm{yr}$ of protection from fishing could have produced such a dramatic change), both our results and those of Ralston \& MacFarlane (2010) indicate that the CCA is strategically placed to protect an important source of bocaccio production.

Although bocaccio larvae were much more likely to be found in the CCA relative to the surrounding region, considerable heterogeneity in the presence of larvae within the CCA was also evident. A significant proportion of the variability in the presence of recently hatched ( 0 to $1 \mathrm{~d}$ old) larvae was explained by depth. This was also observed by Taylor et al. (2004), but low sample sizes (only 12 bocaccio larvae) prevented a rigorous analysis of the relationship between bocaccio larvae and depth. By contrast, we collected nearly 100 larvae $\mathrm{yr}^{-1}$ and found a highly statistically significant relationship between depth and recently hatched (but not preflexion or postflexion) larvae.

In addition to depth (all years), chlorophyll a (2002, 2003) or sea surface temperature (2004) also ex- 
plained the presence of recently hatched larvae, suggesting that oceanographic heterogeneity affects spawning output within this MPA. In particular, these young larvae tended to be most common in the chlorophyll-elevated or cooler waters in the western region of the CCA. This pattern may reflect the influence of long-term oceanographic conditions on the suitability of habitat for adult bocaccio. The CCA encompasses a highly dynamic oceanographic region that is characterized by an abrupt gradient in sea surface temperature (Hamilton et al. 2010) that is induced by the southward-flowing California Current that transports relatively cool, fresh and nutrient-rich subarctic water into the SCB. Although the boundary of the California Current changes annually (Bograd \& Lynn 2003), average sea surface temperatures between 1982 and 2006 were $3^{\circ} \mathrm{C}$ cooler along the western banks associated with the Santa Rosa Ridge (Potato, Cherry, Cortes and Tanner banks) than along the eastern Osborne Bank; recently hatched bocaccio larvae are also more common along the western banks (Hamilton et al. 2010). Additionally, the community composition of shallow $(<25 \mathrm{~m})$, benthic fishes differs among islands within the cool and warm sides of this temperature gradient (Hamilton et al. 2010). As such, it is possible that primary production is consistently higher on western than eastern CCA banks. High primary production will likely cascade up the food chain and ultimately provide greater food resources for top predators such as adult bocaccio that live in this region. Because food limitation is known to inhibit rockfish reproduction (Norton \& MacFarlane 1995), it is possible that bocaccio residing in the more productive western CCA banks typically produce more larvae than those on the eastern banks. These results suggest that heterogeneity in oceanographic conditions at a relatively fine scale can impact bocaccio productivity and highlight the importance of considering multiple environmental conditions for explaining variation in fish spawning output.

In contrast to recently hatched larvae, the measured environmental parameters were less effective in explaining the variation in the presence of preflexion larvae, suggesting that older fish disassociate from natal habitat. In fact, although depth significantly influenced the presence of both recently hatched and preflexion larvae in 2003, the relationship was positive for recently hatched, but negative for preflexion fish. While many studies have evaluated how the environment affects ichthyoplankton assemblages during the past 2 decades (see review by Govoni 2005), examinations that use stage-specific larvae are rare. Our finding, however, suggest that significant patterns may be obscured if larvae of different ages are combined into one group because advection by currents or active swimming behavior can expose fishes to highly variable environmental conditions during their early life history stages. For example, covariates consistently explained more of the variation in the assemblage structure of fish eggs than larvae in southern France, likely because eggs were exposed to less environmental variation than larvae (Roussel et al. 2010). These results suggest that age-specific data will improve the capacity of statistical models to explain variation in larval fish assemblages.

Evaluation of size-specific larval distributions can also be a powerful approach for gauging dispersal pathways of marine fishes with pelagic larvae (Reiss et al. 2000). For example, larval sizes of 3 species of fish increased with latitude along the east coast of the USA, suggesting that larvae spawned near Cape Hatteras, North Carolina were subsequently transported north within Gulf Stream-associated warm water rings (Hare et al. 2002). Within the SCB, spring-time sampling showed that, some, but not all, species of rockfish larvae cluster around PSH within $1 \mathrm{~d}$ of hatching, and are retained within the SCB by the cyclonic Southern California Eddy (Taylor et al. 2004). Although the Southern California Eddy is a semi-permanent feature predominately centered near the northwestern portion of the CCA $\left(33.5^{\circ} \mathrm{N}\right.$, $119^{\circ} \mathrm{W}$, Chereskin \& Trunnell 1996), it typically increases in prominence during the spring and summer months (Owen 1980, Lynn \& Simpson 1987), later than when our study was conducted. Despite its relatively large size (extending over entire SCB) and the consequent difficulty this creates for resolving the Southern California Eddy using CalCOFI grid observations (Owen 1980), there was no strong evidence that this feature was prevalent during our study (Schwing et al. 2002, Venrick et al. 2003, Goericke et al. 2004). It is important to note, however, that circulation patterns in the SCB are complicated by local wind forcing, that coupled with the many topographic features such as islands and banks within the region (Hickey 1979, Owen 1980), can generate small (1 to $50 \mathrm{~km}$ wide) coastal eddies (Owen 1980, DiGiacomo \& Holt 2001, Marmorino et al. 2010). While these eddies appear to be primarily distributed north of our study site (associated with the Santa Barbara Channel and Santa Monica-San Pedro Basin) during the winter months, cyclonic eddies have been observed in the eastern part of the CCA (DiGiacomo $\&$ Holt 2001) and might thus also impact larval trans- 
port. In contrast to recently hatched larvae, later larval stages were not significantly associated with PSH (despite their relative high abundance in the CCA), suggesting that these stages were transported away from their point of natal origin. As inferred by the distributions of later stage larvae, larval transport paths likely varied among years as a result of fluctuating currents within the SCB.

The SCB circulation patterns (CalCOFI-scale) in 2002 were characterized by a strong meander in the California Current offshore of the CCA, an anticyclonic loop at the western edge of the CCA near Potato Bank, and a more offshore than usual Southern California Countercurrent (Schwing et al. 2002). The highest chlorophyll a values we observed in our study also corresponded to the impinging cyclonic current loop within the northwest corner of the CCA (Schwing et al. 2002). CCA currents were measured starting approximately $2 \mathrm{wk}$ prior to the CCA larval surveys, and net current flow was to the northwest. This might help explain why most postflexion larvae were found in the northern portion of the study area.

Conditions changed in 2003 when an El Niño event brought warmer and less productive waters than usual into the SCB (Venrick et al. 2003). The California Current jet remained offshore of the CCA, while a strong Southern California Countercurrent developed nearshore (Venrick et al. 2003), which is characteristic of El Niño conditions (Bograd \& Lynn 2003). Currents and larval abundances were measured concurrently, and dynamic height anomalies (Venrick et al. 2003) as well as our current vector plots (Fig. 10B) indicate the presence of a cyclonic recirculation over the CCA. Cyclonic circulations also correspond to cold anomalies (Taylor et al. 2004) and, indeed, the coldest water was located around Potato Bank and north of Cherry Bank during our study, where the center of the eddy was located. Flows were largely northeastward in the southern portion of the CCA and preflexion larvae were found in the basin north of Tanner Bank and extended around Osborne Bank, primarily northeast of PSH. This indicates that preflexion larvae were influenced by ocean currents as they were transported away from natal habitats. Larval retention within the CCA due to the recirculation feature, however, was likely high during this time period.

Finally, in 2004, cooler conditions returned to the $\mathrm{SCB}$, and the California Current meandered along the western boundary of the CCA (Goericke et al. 2004) where we observed cooler water around Potato Bank. In contrast to 2003, the Southern California Countercurrent was weak (Goericke et al. 2004). In
2004, currents were measured approximately $20 \mathrm{~d}$ prior to larval sampling and while currents varied within the CCA, net current flow was southwest. This suggests that pre- and postflexion larvae, primarily found south of PSH, likely originated from the northern CCA. An area of converging currents between Osborne and Potato Banks also corresponded to relatively high larval abundances. Further elucidation of larval transport pathways and the physical features that impact them within the CCA requires synoptic spatiotemporal sampling of larval abundances and flow fields; however, our results indicate that interannual variability in the magnitude and direction of flow affects larval transport patterns, which is similar to findings generated by theoretical circulation models in the SCB (Siegel et al. 2008, Mitarai et al. 2009).

Two particularly striking results of our study were that overall larval abundances increased from 2002 to 2004 and that later-stage (pre- and postflexion) larvae were much more abundant in 2004 relative to other years. There are several potential explanations for these findings. One possibility is that sampling took place later in the bocaccio spawning season in 2004 relative to the other years. Although the timing of the CCA cruises was intended to coincide with peak rockfish spawning, the overall period of bocaccio reproduction in Southern California occurs between December and March (Moser et al. 2000), and the exact timing of peak spawning can vary among years (Woodbury \& Ralston 1991). As such, if samples were collected weeks after the peak in 2004 but not in other years, then more later-stage larvae would turn up in 2004 samples even if survival was similar among years. This scenario, however, would explain the increase in older, but not recently hatched larvae in 2004. A second possible explanation for the increase in later-stage larvae is that more fish were advected into our sample frame in 2004 than in other years. Although overall current flows were relatively low and constant in each year, 2004 was the only year when mean current directions were southward. Hence, if substantial spawning occurred north of the $\mathrm{CCA}$, then these larvae may have been more likely to enter the sample frame in 2004 relative to 2002 and 2003. Again, however, this would not account for the increase in recently hatched larvae in 2004.

A third potential explanation for the increase in overall and later-staged larvae in 2004 is that output and/or survival was higher in this year, perhaps as a result of the protection afforded to bocaccio by the CCA. Although high production and/or survival may simply reflect favorable environmental conditions in 2004 when temperature was relatively low and 
chlorophyll a high, these parameters were very similar in 2002. A potential contributing factor, therefore, is that 2 additional years of protection from fishing pressure allowed female bocaccio to grow larger and produce higher quality larvae. Studies on maternal effects in rockfishes have demonstrated that bocaccio in particular exhibit weight-specific fecundity with the number of vitellogenic eggs approximately doubling between 2 and $4 \mathrm{~kg}$ females (Ralston \& MacFarlane 2010), and that older, larger adults produce larvae with more endogenous energy reserves provided in an oil globule, an energy-rich package that sustains larvae after parturition (Berkeley et al. 2004, Sogard et al. 2008). As such, it is likely that larger female bocaccio not only produce more larvae than younger females, but that the larvae from older spawners will grow faster and survive starvation longer than larvae from younger females (Hislop 1988, Berkeley et al. 2004). Hence, the cessation of fishing-induced mortality may have eased the elimination of larger, older fish, and had a positive effect on both larval output and quality (Pope 2009, Ralston \& MacFarlane 2010) in a year with favorable environmental conditions. The idea that larval survival was relatively high in 2004 was supported by the fact that bocaccio recruitment success (number of recruits per spawners) was much greater in 2004 than in 2002 or 2003 (Zabel et al. 2011). Additionally, when recruitment success was modeled against environmental variability, success was greater in 2004 than the model predicted (Zabel et al. 2011). Although our study was not explicitly designed to test the effect of the CCA on bocaccio production, these results suggest that cessation of fishing-induced mortality may have resulted in an increased larval output/survival within its bounds 3 yr after it was established.

\section{CONCLUSIONS}

The essential fish habitat mandate of the US Magnuson-Stevens Fishery Conservation and Management Act represents an effort to integrate fisheries and habitat management by studying the ecological relationships between fishery resources and the environment upon which they depend (Copps et al. 2007). Based on limited information on essential fish habitat for most of the 82 species in its groundfish management plan, the Pacific States Fisheries Management Council has conservatively identified the entire continental shelf of the US West Coast as essential fish habitat (Pacific Fisheries Management Council 2005, Gallagher \& Heppell 2010). Our results show that the CCA is protecting important bocaccio spawning grounds but that the presence of this habitat is heterogeneous within its bounds. Specifically, the probability of detecting a newly spawned bocaccio was significantly greater in shallower regions and those with either high chlorophyll a concentrations or relatively cool temperatures. Furthermore, because many rockfishes have similar life history requirements to bocaccio (Love et al. 2002), it is likely that the CCA encompasses essential habitat for other species. For example, results from a 2002 assessment of Sebastes levis also suggested that essential habitat was found for this species in the CCA (Yoklavich et al. 2007). Thus, it appears that the bounds of the CCA includes essential fish habitat that is important for the persistence of bocaccio and likely other rockfishes in Southern California.

Acknowledgements. Data were collected and provided by the Southwest Fisheries Science Center and the crew of the RV 'New Horizon'. We are particularly grateful to S. Charter, S. McClatchie, R. Vetter, W. Watson, and for their input, imparting their knowledge about the ecology of larval fishes, and teaching larval fish identification. Z. Yin helped with geographic information systems and S. Searcy assisted with otolith ageing. This manuscript was greatly improved by comments from Z. Yin, S. Searcy, W. Watson and 4 anonymous reviewers. Financial support was provided by the Hannon Fellowship administered by the University of San Diego.

\section{LITERATURE CITED}

Ahlstrom EH (1959) Vertical distribution of pelagic fish eggs and larvae off California and Baja California. US Fish Wld S Fish B 60:107-146

> Augustin NH, Muggelstone MA, Buckland ST (1996) An autologistic model for the spatial distribution of wildlife. J Appl Ecol 33:339-347

> Berkeley SA, Chapman C, Sogard SM (2004) Maternal age as a determinate of larval growth and survival in a marine fish, Sebastes melanops. Ecology 85:1258-1264

Bivand R (2012) Spatial dependence: weighting schemes, statistics and models. R package version 0.5-46. cran.rproject.org/package=spdep

Bograd S, Lynn RJ (2003) Long-term variability in the Southern California Current System. Deep-Sea Res II 50: 2355-2370

Burnham KP, Anderson DR (2002) Model selection and multimodel inference: a practical information-theoretic approach. Springer, New York, NY

Butler JL, Jacobson LD, Barnes JT, Moser HG (2003) Biology and population dynamics of cowcod (Sebastes levis) in the southern California Bight. Fish Bull 101:260-280

California Department of Fish and Game (2008) California Marine Life Protection Act: Master plan for marine protected areas. www.dfg.ca.gov/mlpa/masterplan.asp

Chereskin TK, Trunnell M (1996) Correlation scales, objective mapping, and absolute geostrophic flow in the Cali- 
fornia Current. J Geophys Res 101:22619-22629

Copps S, Yoklavich M, Parkes G, Wakefield W and others (2007) Applying marine habitat data to fishery management on the US west coast: initiating a policy-science feedback loop. In: Todd B, Greene HG (eds) Mapping the seafloor for habitat characterization. Geol Assoc Canada, Special Paper 47, p 451-462

Cressey D (2011) Ocean conservation: uncertain sanctuary. Nature 480:166-167

Di Lorenzo E (2003) Seasonal dynamics of the surface circulation in the Southern California Current System. DeepSea Res II 50:2371-2388

DiGiacomo PM, Holt B (2001) Satellite observations of small coastal ocean eddies in the Southern California Bight. J Geophys Res 106(C10):22521-22544

> Dormann CF, McPherson JM, Araújo MB, Bivand R and others (2007) Methods to account for spatial autocorrelation in the analysis of species distributional data: a review. Ecography 30:609-628

Doyle MJ, Picquelle SJ, Mier KL, Spillane MC, Bond NA (2009) Larval fish abundance and physical forcing in the Gulf of Alaska, 1981-2003. Prog Oceanogr 80:163-187

Emery WJ, Thomson RE (2001) Data analysis methods in physical oceanography, 2nd edn. Elsevier Science, Amsterdam

Field JC, MacCall AD, Ralston S, Love MS, Miller EF (2010) Bocaccionomics: the effectiveness of pre-recruit indices for assessment and management of bocaccio. Calif Coop Ocean Fish Invest Rep 51:77-90

Gallagher MB, Heppell SS (2010) Essential habitat identification for age-0 rockfish along the central Oregon coast. Marine and Coastal Fisheries: Dynamics, Management, and Ecosystem Science 2:60-72

Gell FR, Roberts CM (2003) Benefits beyond boundaries: the fishery effects of marine reserves. Trends Ecol Evol 18: 448-455

Goericke R, Venrick E, Mantyla A, Bograd SJ and others (2004) The state of the California Current, 2003-2004: a rare 'normal' year. Calif Coop Ocean Fish Invest Rep 45: 27-59

> Govoni JJ (2005) Fisheries oceanography and the ecology of early life histories of fishes: a perspective over fifty years. Sci Mar 69:125-137

Halpern BS (2003) The impact of marine reserves: Do reserves work and does reserve size matter? Ecol Appl 13:117-137

Halpern BS, Waldbridge S, Selkoe KA, Kappel CV, Micheli $\mathrm{F}$ and others (2008) A global map of human impact on marine ecosystems. Science 319:948-952

Halpern BS, Lester SE, McLeod KL (2010) Placing marine protected areas onto the ecosystem-based management seascape. Proc Natl Acad Sci USA 107:18312-18317

Hamilton SL, Caselle JE, Malone DP, Carr MH (2010) Incorporating biogeography into evaluations of the Channel Islands marine reserve network. Proc Natl Acad Sci USA 107:18272-18277

Hare JA, Churchill JH, Cowen RK, Berger TJ and others (2002) Routes and rates of larval fish transport from the southeast to the northeast United States continental shelf. Limnol Oceanogr 47:1774-1789

Hewitt RP (1988) Historical review of the oceanographic approach to fishery research. Calif Coop Ocean Fish Invest Rep 29:27-41

> Hickey BM (1979) The California Current Systemhypotheses and facts. Prog Oceanogr 8:191-279
Hickey BM (1993) Physical oceanography. In: Dailey MD, Reish DJ, Anderson JW (eds) Ecology of the Southern California Bight. University of California Press, Berkeley, CA, p 19-70

Hickey BM, Dobbins EL, Allen SE (2003) Local and remote forcing of currents and temperature in the central Southern California Bight. J Geophys Res 108(C3):1-26

Hislop JRG (1988) The influence of maternal length and age on size and weight of the eggs and the relative fecundity of the haddock, Melanogrammus aeglefinus, in British water. J Fish Biol 32:923-930

Hitchman SM (2011) Age-specific association with potential adult habitat in larval bocaccio, Sebastes paucispinis, in the Southern California Bight. MS thesis, University of San Diego, CA

Jackson JBC, Kirby MX, Berger WH, Bjorndal KA and others (2001) Historical overfishing and the recent collapse of coastal ecosystems. Science 293:629-637

Kahru M, Mitchell BG (1999) Empirical chlorophyll algorithm and preliminary SeaWiFS validation for the California Current. Int J Remote Sens 20:3423-3429

Kramer D, Kalin MJ, Stevens EG, Thrailkill JR, Zweifel JR (1972) Collecting and processing data on fish eggs and larvae in the California Current Region. NOAA Tech Rep NMFS Circ

Laidig TE, Ralston S (1995) The potential use of otoliths characters in identifying larval rockfish (Sebastes spp.). Fish Bull 93:166-171

Laidig TE, Ralston S, Bence JR (1991) Dynamics of growth in the early life history of shortbelly rockfish, Sebastes jordani. Fish Bull 89:611-621

Lenarz WH, Larson RJ, Ralston S (1991) Depth distributions of late larvae and pelagic juveniles of some fishes of the California Current. Calif Coop Ocean Fish Invest Rep 32: $41-46$

> Lester SE, Halpern BS, Grorud-Colvert K, Lubchenco J and others (2009) Biological effects within no-take marine reserves: a global synthesis. Mar Ecol Prog Ser 384:33-46

Love MS, Yoklavich M, Thornsteinon L (2002) The rockfishes of the northeast Pacific. University of California Press, Berkeley, CA

Lynn RJ, Simpson JJ (1987) The California Current system: the seasonal variability of its physical characteristics. J Geophys Res 92:12947-12966

MacCall AD (2003) Status of bocaccio off California in 2003. In: Status of the Pacific Coast Groundfish Fishery through 2003, Stock Assessment and Fishery Evaluation: Stock Assessments and Rebuilding Analyses. Pacific Fisheries Management Council, Portland, OR. www.pcouncil. org/wp-content/uploads/Bocaccio_2003_Assessment.pdf

Marmorino GO, Holt B, Molemaker MJ, DiGiacomo PM, Sletten MA (2010) Airborne synthetic aperture radar observations of 'spiral eddy' slick patterns in the Southern California Bight. J Geophys Res 115(C5):C05010

Mazerolle MJ (2011) AICcmodavg: model selection and multimodel inference based on (Q)AIC(c). R package, version 1.21. http://cran.r-project/web/packages/AICC modavg/

Mitarai S, Siegel DA, Watson JR, Dong C, McWilliams JC (2009) Quantifying connectivity in the coastal ocean with application to the Southern California Bight. J Geophys Res 114:C10026

Moser HG (1996) The early life stages of fishes in the California Current Region. Calif Coop Ocean Fish Invest Rep Atlas 33 
Moser HG, Smith PE (1993) Larval fish assemblages of the California Current region and their horizontal and vertical distributions across a front. Bull Mar Sci 53:645-691

Moser HG, Charter RL, Watson W, Ambrose DA, Butler JL, Charter SR, Sandknop EM (2000) Abundance and distribution of rockfish (Sebastes) larvae in the Southern California Bight in relation to environmental conditions and fishery exploitation. Calif Coop Ocean Fish Invest Rep 41:132-147

National Oceanic and Atmospheric Administration (2006) Magnuson-Stevens Act Provisions, Fisheries off West Coast States, Pacific Coast Groundfish Fishery. Federal Register 50 CFR Part 660 (docket number 0512133346119-02; I.D. 112905C), RIN 0648-AT98. www.nmfs.noaa. gov/msa2007/

Norton EC, MacFarlane RB (1995) Nutritional dynamics of reproduction in viviparous yellowtail rockfish, Sebastes flavidus. Fish Bull 92:299-307

Owen RW (1980) Eddies of the California Current System: physical and ecological characteristics. In: Power DM (ed) The California islands: proceedings of a multidisciplinary symposium. Santa Barbara Museum of Nat History, Santa Barbara, CA, p 237-263

Pacific Fisheries Management Council (2005) Groundfish essential habitat draft Environmental Impact Statement (CH2 EIS). PFMC, Portland, OR

Pelc RA, Baskett ML, Tanci T, Gaines SD, Warner RR (2009) Quantifying larval export from South African reserves. Mar Ecol Prog Ser 394:65-78

Penney RW, Evans GT (1985) Growth histories of larval redfish (Sebastes spp.) on an offshore Atlantic fishing bank determined by otolith increment analysis. Can J Fish Aquat Sci 42:1452-1464

Pope JG (2009) Stock assessment models and predictions of catch and biomass. In: Jakobsen T, Fogarty MJ, Megrey BA, Moksness E (eds) Fish reproductive biology: implications for assessment and management. Wiley-Blackwell, Oxford, p 254-292

Quinn GP, Keough MJ (2002) Experimental design and data analysis for biologists. Cambridge University Press, Cambridge

R Development Core Team (2010) R: A language and environment for statistical computing. R Foundation for Statistical Computing, Vienna. www.R-project.org

Ralston S (1976) Age determination of tropical reef butterfly fish utilizing daily growth rings of otoliths. Fish Bull 74: 990-994

Ralston S, MacFarlane BR (2010) Population estimation of bocaccio (Sebastes paucispinis) based on larval production. Can J Fish Aquat Sci 67:1005-1020

Ralston S, Brothers EB, Roberts DA, Sakuma KM (1996) Accuracy of age estimates for larval Sebastes jordani. Fish Bull 94:89-97

Reiss CS, Panteleev G, Taggart CT, Sheng J, DeYoung B (2000) Observations on larval fish transport and retention on the Scotian Shelf in relation to geostrophic circulation. Fish Oceanogr 9:195-213

Ross JRM, Larson K (2003) Influence of water column stratification on the depth distributions of pelagic juvenile rockfishes off central California. Calif Coop Ocean Fish Invest Rep 44:65-75

Editorial responsibility: Nicholas Tolimieri, Seattle, Washington, USA
Roussel E, Crec'hriou R, Lenfant P, Mader J, Planes S (2010) Relative influences of space, time and environment on coastal ichthyoplankton assemblages along a temperate rocky shore. J Plankton Res 32:1443-1457

Schwing FB, Bograd SJ, Collins CA, Gaxiola-Castro G and others (2002) The state of the California Current, 2001-2002: Will the California Current system keep its cool, or is El Niño looming? Calif Coop Ocean Fish Invest Rep 43:31-68

Siegel DA, Mitarai S, Costello CJ, Gaines SD, Kendall BE, Warner RR, Winters KB (2008) The stochastic nature of larval connectivity among nearshore marine populations. Proc Natl Acad Sci USA 105:8974-8979

Smith PE, Richardson SL (1977) Standard techniques for pelagic fish egg and larval surveys. FAO Fish Tech Pap 175:100pp

Sogard SM, Berkeley SA, Fisher R (2008) Maternal effects in rockfishes Sebastes spp: a comparison among species. Mar Ecol Prog Ser 360:227-236

Taylor CA, Watson W, Chereskin T, Hyde J, Vetter R (2004) Retention of larval rockfishes, Sebastes, near natal habitat in the Southern California Bight, as indicated by molecular identification methods. Calif Coop Ocean Fish Invest Rep 45:152-166

Thompson AR, Watson WW, McClatchie S, Weber ED (2012) Multi-scale sampling to evaluate assemblage dynamics in an oceanic marine reserve. PLoS ONE 7:e33131

> Tolimieri N, Levin PS (2005) The roles of fishing and climate in the population dynamics of bocaccio rockfish. Ecol Appl 15:458-468

Venrick E, Bograd SJ, Checkley D, Durazo R and others (2003) The state of the California Current, 2002-2003: tropical and subarctic influences vie for dominance. Calif Coop Ocean Fish Invest Rep 44:28-60

Watson W, Charter RL, Moser HG, Ambrose DA, Charter SR, Sandknop EM, Robertson LL, Lynn EA (2002) Distributions of planktonic fish eggs and larvae off two state ecological reserves in the Santa Barbara Channel vicinity and two nearby islands in the Channel Islands National Marine Sanctuary, California. Calif Coop Ocean Fish Invest Rep 43:141-154

Woodbury D, Ralston S (1991) Interannual variation in growth rates and back-calculated birthdate distributions of pelagic juvenile rockfishes (Sebastes sp.) off the central California coast. Fish Bull 89:523-533

Worm B, Barbier EB, Beaumont N, Duffy JE and others (2006) Impacts of biodiversity loss on ocean ecosystem services. Science 314:787-790

Yoklavich MM, Loeb VJ, Nishimoto M, Daly B (1996) Nearshore assemblages of larval rockfishes and their physical environment off central California during an extended El Niño event, 1991-1993. Fish Bull 94:766-782

> Yoklavich MM, Love MS, Forney KA (2007) A fisheryindependent assessment of an overfished rockfish stock, cowcod (Sebastes levis), using direct observations from an occupied submersible. Can J Fish Aquat Sci 64: 1795-1804

Zabel RW, Levin PS, Tolimieri N, Mantua NJ (2011) Interactions between climate and population density in the episodic recruitment of bocaccio, Sebastes paucispinis, a Pacific rockfish. Fish Oceanogr 20:294-304

Submitted: February 29, 2012; Accepted: July 5, 2012

Proofs received from author(s): September 25, 2012 